\title{
Lacrimal sac topography myiais
}

\author{
Miíase na topografia de saco lacrimal
}

Simone Haber Duellberg von Faber Bison', Marco Antonio de Campos Machado', João Amaro Ferrari Silva', Eduardo Alonso Garcia², Mirtha Alicia Ramirez Dittrich ${ }^{3}$

\begin{abstract}
Myiasis is the invasion of human tissues by Diptera larvae. Ocular involvement is rare. The objective of this paper is to report a case of myiasis in the topography of the lacrimal sac and discuss current treatments for this disease.
\end{abstract}

Keywords: Lacrimal sac/pathology; Myiasis/therapy; Case reports

\section{RESUMO}

A miíase é a infestação dos tecidos humanos por larvas Diptera. O comprometimento ocular é raro. Os autores apresentam um caso de miíase na topografia do saco lacrimal e discutem as modalidades terapêuticas para o tratamento desta doença.

Descritores: Saco lacrimal/patologia; Miíase/terapia; Relato de casos

1,3 Escola Paulista de Medicina, Universidade Federal de São Paulo, São Paulo, SP, Brazil.

2 Escola Paulista de Medicina, Universidade Federal de São Paulo, São Paulo, SP, Brazil; Santa Casa da Misericórdia de Santos, Santos, SP, Brazil.

Lacrimal Pathways Sector of the Department of Ophthalmology and Visual Sciences of the Universidade Federal de São Paulo and Escola Paulista de Medicina.

The authors declare no conflicts of interests.

Received for publication 24/06/2014 - Accepted for publication 04/08/2014 


\section{INTRODUCTION}

$\mathbf{M}$ yiasis is a zoonotic disease characterized by the infestation of live or dead tissues of vertebrates by larval stages of certain diptera flies and that affects a wide variety of animals. The human myiasis affects mainly individuals from rural areas, as shepherds and farmers. ${ }^{1}$ This disease has been reported in many regions of the world. ${ }^{2}$

There are two main types of myiasis: the external and the internal ones. The external Myiasis includes the skin type, which is the most common one, and the ocular and the auditory ones. The internal myiasis includes gastric, intestinal and urogenital infestations. ${ }^{3}$

The ocular involvement is uncommon, but when present, the conjunctival myiasis is its most common expression. ${ }^{4}$

The authors present a case report of myiasis in the topography of the lacrimal sac with no history of trauma in the region, simulating dacryocystitis.

\section{Case Report}

JVC, 38 years, construction worker, was admitted to the emergency room complaining of discomfort in the region of the lacrimal sac of the RE for 7 days. He reported progressive worsening of symptoms. The ectoscopy had a hardened nodular lesion and hyperemia in the area of the lacrimal sac with fistula, without secretion and with slight pain on palpation.

He was suspected of acute dacryocystitis, and was treated with cephalexin $500 \mathrm{mg}$ (orally) every 6 hours for 5 days, and with warm compresses.

No additional exams were carried out. The patient had no clinical improvement and mentioned feeling something moving on the site.

We decided to take him to the operating room. We performed an infiltration with $3,0 \mathrm{ml}$ of lidocaine (Xylocaine ${ }^{\circledR}$ ) at the lesion site and lidocaine (Xylocaine $\left.{ }^{\circledR}\right)$ gel in the ostium of the lesion, which caused the exit of a larva through the hole in the lacrimal sac region (Figures 1 and 2).

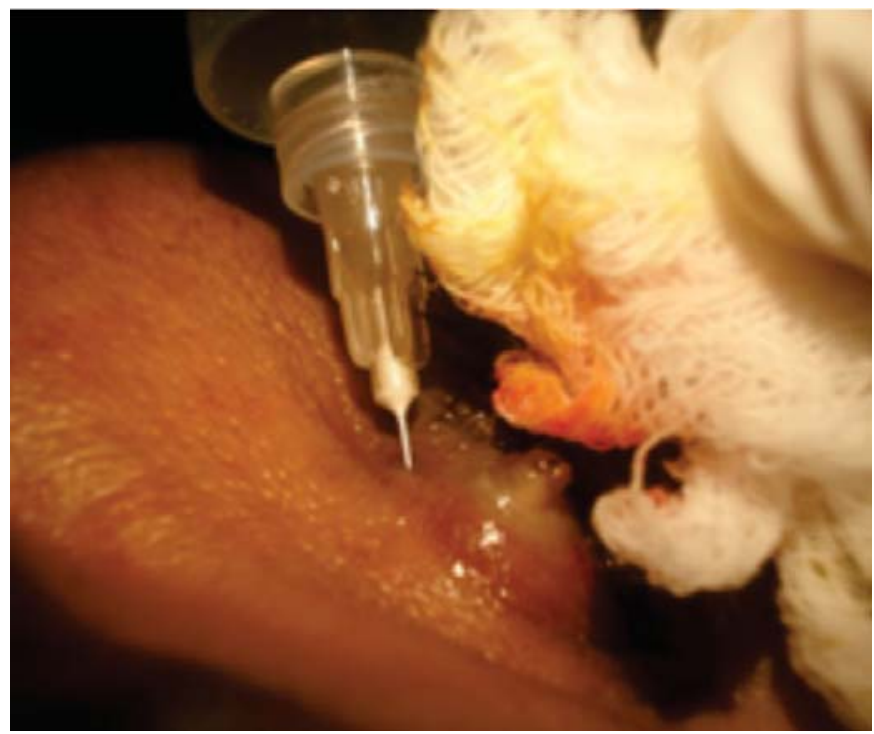

Figure 1: Lidocaine infiltration, in which the head of the larva can be seen coming out through the hole in the topography of the right lacrimal sac.

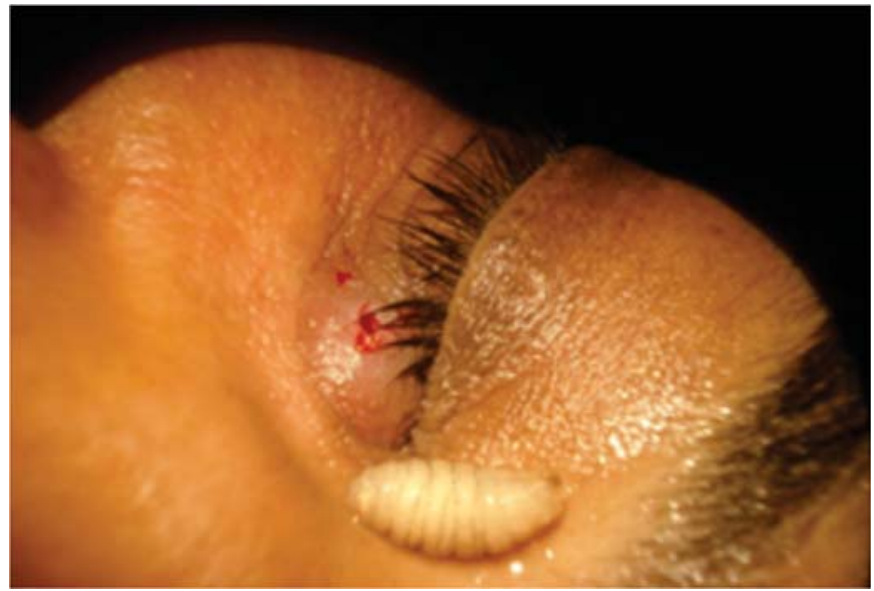

Figura 2: Detail of the larvae removed in the topography of the lacrimal sac.

\section{Discussion}

The first reports of myiasis in the man and other animals date from the 16th century in the Neotropics. ${ }^{5}$ Myiasis can be classified according to the location, as well as in parasitological terms based on host-parasite relationship.

Various species of flies have medical relevance due to infecting humans. Among them in Brazil there are Cochliomya hominivorax, Cochliomia macellaria and Dermatobia hominis. ${ }^{6}$

Ophthalmomyiasis comprises the eyeball and conjunctival myiasis. The main symptoms in this form of manifestation are severe pain, edema, conjunctival hyperemia, foreign body sensation and abundant tear secretion. ${ }^{7}$ The diagnosis is essentially clinical.

The parasitic infection of the lacrimal system is rare. ${ }^{8}$ Although unusual, the ophthalmomyiasis should be considered as a possible diagnosis in cellulite not responsive to conventional treatment, especially in endemic areas.

The treatment consists basically in the elimination of the larvae, either mechanically or chemically, through the use of medication or anesthetic substances. ${ }^{6}$

Lidocaine is a slightly acidic substance with ph ranging from 4.5 to 6.0. Thus, it acts as a extremely irritating agent to the larvae, causing their output from where they are. ${ }^{9}$

The lesion expression maneuvers are contraindicated in furuncular myiasis, since the parasite will resist due to the oral hooks attached to the tissues. Thus, untimely measures almost always cause the fragmentation of parasitic organism, providing site suppuration and severe infection. ${ }^{10}$

In some cases the infestation can be massive, involving the entire orbit and extending to the neighboring structures and the paranasal sinuses, which makes the mechanical removal of the larvae more difficult. ${ }^{11}$

In these cases, the myiasis also can be effectively treated with ivermectin, a broad-spectrum antiparasitic agent, thereby reducing the scale of need of exploratory surgery. ${ }^{12}$ Since 1993 , this medicine has been considered safe for human use when administered orally in a single dosage of 300 micrograms/Kg. ${ }^{13}$

\section{REFERENCES}

1. Abdellatif MZ, Elmazar HM, Essa AB. Oestrus ovis as a cause of red eye in Aljabal Algharbi, Libya. Middle East Afr J Ophthalmol. 2011; 18 (4): 305-8. 
2. Sucilathangam G, Meenakshisundaram A, Hariramasubramanian S, Anandhi D, Palaniappan N, Anna T. External ophthalmomyiasis which was caused by sheep botfly (oestrus ovis) larva: a report of 10 cases. J Clin Diagn Res. 2013; 7 (3): 539-42.

3. White GB. Myiasis. Cook GC, editors. Manson's tropical diseases, 20th ed. Oxford: Saunders; 1996. p.1755.

4. Corrin R, Scholten T, Earle J. Ocular myiasis: mobile conjunctival foreign body. Can Med Assoc J. 1985; 132(11):1291-2.

5. Guimarães JH, Papavero N. Myiases in men and animals in the neotropical region. Bibliographic Database. São Paulo: Editora Plêiade; 1999.

6. Marquez AT, Mattos MS, Nascimento SB. Miíases associadas com alguns fatores sócio-econômicos em cinco áreas urbanas do Estado do Rio de Janeiro. Rev Soc Med Trop. 2007;40(2):175-80.

7. Donoso Barros R. Myiasis humana em Chile. Consideraciones clínicas y epidemiológicas. Rev Chil Hig Med Prevent. 1947;9(1):3-40.

8. Saraiva FP, Fernandes JB, Tomikawa VO, Costa PG, Matayoshi S. Ophthalmomyiasis as a cause of canalicular lesion. J Pediatr (Rio J). 2005;81(1):85-7.

9. Wannmacher L, Ferreira MBC. Farmacologia clínica para dentistas. $2^{\mathrm{a}}$ ed. Rio de Janeiro: Guanabara Koogam; 1999.
10. Woiffenbuttei E. As várias formas de miíases no homem. Sua profilaxia e seus diferentes tratamentos (comprovados e a serem experimentados). Rev Bras Med.1953;10(2):135-9.

11. Melendez JA, Bison SH, Vital Filho J. Míase órbito-maxilo-bucal: relato de caso. Arq Bras Oftalmol. 1995;58(3):204-5.

12. Puthran N, Hegde V, Anupama B, Andrew S. Ivermectin treatment for massive orbital myiasis in an empty socket with concomitant scalp pediculosis. Indian J Ophthalmol. 2012; 60 (3): 225-7.

13. Martin-Prevel Y, Cosnefroy JI, Tshipampa P, Ngari P, Chodakewitz JA, Pinder M. Tolerance and efficacy of single high-dose invermectin for treatment of miiasis. Am J Trop Med Hyg. 1993; 48(2):186-92.

\section{Corresponding author:}

Mirtha Alicia Ramirez Dittrich

Rua Botucatu, 821 - 2nd floor - ZIP Code 04023-062 - São

Paulo (SP)

Email: mar.dittrich@hotmail.com 